\title{
A novel selective $11 \beta$-hydroxysteroid dehydrogenase type 1 inhibitor prevents human adipogenesis
}

\author{
I J Bujalska, L L Gathercole, J W Tomlinson, C Darimont ${ }^{1}$, J Ermolieff ${ }^{2}$, A N Fanjul ${ }^{2}$, P A Rejto ${ }^{2}$ \\ and P M Stewart \\ Division of Medical Sciences, The Medical School, Institute of Biomedical Research, University of Birmingham, Edgbaston, Birmingham B15 2TT, UK \\ ${ }^{1}$ Nestle Research Center, PO Box 44, Vers-Chez-Les-Blanc, 1000 Lausanne 26, Switzerland \\ ${ }^{2}$ Pfizer Global Research and Development, La Jolla Laboratories, 10646 Science Center Drive, San Diego, California 92121, USA \\ (Correspondence should be addressed to P M Stewart; Email: p.m.stewart@bham.ac.uk)
}

\begin{abstract}
Glucocorticoid excess increases fat mass, preferentially within omental depots; yet circulating cortisol concentrations are normal in most patients with metabolic syndrome (MS). At a pre-receptor level, 11 $\beta$-hydroxysteroid dehydrogenase type 1 $(11 \beta-H S D 1)$ activates cortisol from cortisone locally within adipose tissue, and inhibition of $11 \beta-H S D 1$ in liver and adipose tissue has been proposed as a novel therapy to treat MS by reducing hepatic glucose output and adiposity. Using a transformed human subcutaneous preadipocyte cell line (Chub-S7) and human primary preadipocytes, we have defined the role of glucocorticoids and 11ß-HSD1 in regulating adipose tissue differentiation. Human cells were differentiated with $1 \cdot 0 \mu \mathrm{M}$ cortisol $(\mathrm{F})$, or cortisone (E) with or without $100 \mathrm{nM}$ of a highly selective $11 \beta$-HSD1 inhibitor PF-877423. 11 $\beta-H S D 1$ mRNA expression increased across adipocyte differentiation $(P<0 \cdot 001, n=4)$, which was
\end{abstract}

paralleled by an increase in $11 \beta-\mathrm{HSD} 1$ oxo-reductase activity (from nil on day 0 to $5 \cdot 9 \pm 1.9 \mathrm{pmol} / \mathrm{mg}$ per h on day 16 , $P<0 \cdot 01, n=7)$. Cortisone enhanced adipocyte differentiation; fatty acid-binding protein 4 expression increased 312 fold $(P<0 \cdot 001)$ and glycerol-3-phosphate dehydrogenase 47 -fold $(P<0.001)$ versus controls. This was abolished by co-incubation with PF-877423. In addition, cellular lipid content decreased significantly. These findings were confirmed in the primary cultures of human subcutaneous preadipocytes. The increase in $11 \beta$-HSD1 mRNA expression and activity is essential for the induction of human adipogenesis. Blocking adipogenesis with a novel and specific $11 \beta$-HSD1 inhibitor may represent a novel approach to treat obesity in patients with MS.

Journal of Endocrinology (2008) 197, 297-307

\section{Introduction}

Glucocorticoid excess (Cushing's syndrome) causes visceral obesity, insulin resistance, diabetes mellitus, dyslipidaemia, hypertension and premature vascular mortality; as such it represents an excellent paradigm for patients with the metabolic syndrome (MS). However, Cushing's syndrome is rare and circulating glucocorticoid levels are usually normal or even slightly reduced in obese patients (Fraser et al. 1999). At a cellular level, glucocorticoids within human adipose tissue, specifically in omental depots, can be generated from inactive circulating cortisone (in humans) or 11-dehydrocorticosterone (in rodents) through the oxo-reductase activity of $11 \beta$-hydroxysteroid dehydrogenase type 1 (11ß-HSD1; Bujalska et al. 1997b). Transgenic mice with adipose tissue-targeted $11 \beta-H S D 1$ overexpression develop visceral obesity, insulin resistance, hyperlipidaemia and hypertension without altering circulating glucocorticoids (Masuzaki et al. 2001, 2003), while mice with $11 \beta$-HSD1 overexpression in the liver develop MS without obesity (Paterson et al. 2004). Conversely, global deletion of
$11 \beta-H S D 1$ caused reduced visceral fat accumulation and improved insulin sensitivity on a high fat diet (Kotelevtsev et al. 1997, Morton et al. 2004). At a molecular level, glucocorticoids exert potent effects upon adipose tissue; in mature rat adipocytes, dexamethasone decreases glucose uptake and oxidation (Olefsky 1975, De et al. 1981). Glucocorticoids increase lipolysis by up-regulating the expression of the ratelimiting enzyme hormone-sensitive lipase (Slavin et al. 1994), as well as lipogenic enzyme, lipoprotein lipase (Yang et al. 1993). In preadipocytes, glucocorticoids are essential for terminal adipogenesis (Hauner et al. 1987) and limit cell proliferation (Tomlinson et al. 2002). The process of cellular differentiation is a highly synchronized cascade of regulated differentiationdependent gene expression. Genes such as retinoblastoma proteins that regulate the cell cycle (Richon et al. 1997) are followed by adipogenic transcription factors, such as peroxisome proliferator-activated receptor $\gamma(\operatorname{PPAR} \gamma)$ and CCAAT enhancer-binding protein (Rosen \& MacDougald 2006). Mature adipocytes express late differentiation genes involved in lipid metabolism and lipid transport including 
glycerol-3-phosphate dehydrogenase (G3PD) and fatty acidbinding protein 4 (FABP4; Hotamisligil et al. 1996); many of these genes are regulated by glucocorticoids (Wu et al. 1996, Rosen \& MacDougald 2006). Previously, we have shown that non-selective inhibition of $11 \beta-H S D 1$ can prevent human adipocyte differentiation in vitro (Bujalska et al. 1999). The potential for therapeutic intervention has been tested in rodent models where selective $11 \beta$-HSD1 inhibitors lower plasma glucose, improve insulin sensitivity and in some studies reduce body weight in mice (Alberts et al. 2002, Kershaw et al. 2005). However, the potency of these inhibitors has been variable and there are no data on efficacy in human tissue. We report the development of a selective inhibitor against human $11 \beta-H S D 1$, PF-877423 (Pfizer Global R\&D, La Jolla, CA, USA) and the effect of this compound upon adipogenesis in a wellcharacterised differentiating human subcutaneous preadipocyte cell line (Darimont et al. 2003, Qiao et al. 2005) and in primary cultures of subcutaneous human preadipocytes.

\section{Research design and methods}

\section{Recombinant protein assay}

Wild-type recombinant human 11 $\beta$-HSD1 protein (24-292) was used for studying the inhibitor kinetics. Radio-labelled $\left[1,2-{ }^{3} \mathrm{H}\right]$-cortisone was purchased from American Radiolabeled Chemicals Inc (St Louis, MO, USA). NAD (reduced form; NADPH), glucose-6-phosphate (G6P) and G6P dehydrogenase (G6PD) were purchased from SigmaAldrich. All the concentrations reported in the following section are final in the assay buffer. In addition, the enzyme concentrations represent the active concentrations that were determined by active-site titration using a tight-binding inhibitor. The experimental data were fitted by using the non-linear regression analysis software, Grafit (Leatherbarrow (2001) GraFit Version 5, Erithacus Software Ltd, Horley, UK).

The measurement of the in vitro $11 \beta-$ HSD 1 activity was performed in a $100 \mathrm{mM}$ triethanolamine buffer $(\mathrm{pH} 8 \cdot 0)$, containing $200 \mathrm{mM} \mathrm{NaCl}, 0 \cdot 02 \%$-dodecyl $\beta$-D-maltoside, $5 \%$ glycerol and $5 \mathrm{mM} \beta$-mercaptoethanol. A typical reaction for the determination of enzyme activity comprised the following: $5 \mathrm{nM}$ enzyme pre-incubated for at least 30 minutes in the assay buffer in the presence of $500 \mu \mathrm{M}$ NADPH in round-bottom 96-well plates (Costar cat \# 3365). Next, the reaction was initiated by adding a regenerating system (consisting of $2 \mathrm{mM}$ G6P, $1 \mathrm{U} / \mathrm{ml}$ G6PD and $6 \mathrm{mM} \mathrm{MgCl}_{2}$ ) and labelled ${ }^{3} \mathrm{H}$-cortisone as substrate. After an incubation period (30-40 min), $100 \mu \mathrm{l}$ of the assay mixture were transferred to a second empty round-bottom 96-well plate and mixed with an equal volume of dimethylsulphoxide (DMSO) to quench the reaction. Then, a $15 \mu \mathrm{l}$ aliquot of the assay solution was loaded into a C-18 column (Polaris C18-A, 50×4. $6 \mathrm{~mm}$, 5 u, $180 \AA$, Varian; Polaris, Palo Alto, CA, USA connected to an automated High-Throughput Liquid Chromatography instrument (Cohesive Technologies, HTLC, Franklin, MA, USA). The radioactive material from the column was detected with a $\beta$-RAM model 3 Radio-HPLC detector (IN/US, Tampa, FL, USA). Substrate and product peaks were separated by using an isocratic mixture of 38:62 methanol to water $(\mathrm{v} / \mathrm{v})$ at a flow rate of $1.0 \mathrm{ml} / \mathrm{min}$. Under these experimental conditions, the retention time for cortisone and cortisol were 4.5 and $5.5 \mathrm{~min}$ respectively. The initial reaction velocities recorded were in the linear range and were determined by measuring the peak area for cortisol formation with time.

\section{Recombinant protein kinetic analysis}

The inhibition of $11 \beta-H S D 1$ by PF-877423 was analysed by fitting to the equation described below (Equation (1); Morrison 1969) and provided an accurate measurement for the value of $K i_{\text {app }}$ at a fixed concentration of cortisone

$V_{\mathrm{i}}=V_{\mathrm{o}}\left(1-\left(\frac{[E]_{\mathrm{o}}+[I]_{\mathrm{o}}+K i_{\mathrm{app}}-\sqrt{\left(\left[E_{\mathrm{o}}\right]+[I]_{\mathrm{o}}+K i_{\mathrm{app}}\right)^{2}-4[E]_{\mathrm{o}}[I]_{\mathrm{o}}}}{2[E]_{\mathrm{o}}}\right)\right)$

where $[E]_{0}$ and $[I]_{0}$ are the active enzyme and inhibitor concentration respectively; $V_{\mathrm{i}}$ and $V_{\mathrm{o}}$ are the rates of cortisone reduction in the presence or in the absence of inhibitor respectively. Four $K i_{\text {app }}$ values were determined by varying the cortisone concentration while keeping the concentration of NADPH constant at $500 \mu \mathrm{M}$ in the assay buffer. The true inhibition constant, $K_{\mathrm{i}}$, for PF-877423 was then obtained by plotting the $K i_{\text {app }}$ values versus the cortisone concentration, $[C]_{\mathrm{o}}$, and fitting the data using Equation (2) for a competitive inhibitor

$K i_{\text {app }}=K_{i}\left(1+\frac{[C]_{\mathrm{o}}}{K_{m}}\right)$

where $K_{m}$ was the Michaelis-Menten constant for cortisone.

\section{HEK293 and Chubb-S7 cell culture}

HEK293 cells stably transfected with human 11ß-HSD1 (HEK293T1) or 11 $\beta$-HSD2 (HEK293T2) cDNA as described previously (Bujalska et al. 1997a) were used to study the specificity of inhibitor PF-877423 upon $11 \beta$-HSDs. Cells were cultured in minimum essential medium (MEM) media supplemented with 10\% fetal bovine serum (FBS) and $1 \%$ non-essential fatty acids; for experiments, cells were seeded into 24-well tissue culture dishes and maintained in MEM with 10\% FBS until confluence.

The Chub-S7 cell line was derived from human subcutaneous adipose tissue (Darimont et al. 2003) by co-expression of human telomerase reverse transcriptase and papillomavirus E7 
oncoprotein (HPV-E7) genes. The cell line has an unlimited life span and the capacity to accumulate lipid without chromosomal alteration. Confluent Chub-S7 cells were cultured in $75 \mathrm{~cm}^{2}$ TC flasks in DMEM/Ham's F-12 medium supplemented with 10\% FBS. For experiments, cells were seeded in 24-well plates at density $10^{5}$ cells/well. Chub-S7 were differentiated (up to 21 days) according to Hauner et al. (1987) with $166 \mathrm{nM}$ human insulin (I-9278 Sigma), $1 \mu \mathrm{M}$ PPAR $\gamma$ agonist (GW1929, Camlab, Cambridge, UK) and, where specified, with the addition of $1 \mu \mathrm{M}$ cortisol $(\mathrm{F})$. For inhibition studies, Chub-S7 cells were differentiated with $0.5 \mu \mathrm{M}$ cortisone (E) and an optimised concentration of the selective $11 \beta$-HSD1 inhibitor, PF-877423, at a final concentration of $100 \mathrm{nM}$.

\section{Human subcutaneous stromal-vascular cell differentiation}

Confluent human subcutaneous stromal-vascular $(s-v)$ cells (96-well plates) were obtained from Zen-Bio Inc. (Research Triangle Park, NC, USA) and allowed to recover overnight at $37{ }^{\circ} \mathrm{C} 5 \% \mathrm{CO}_{2}$. The following day, day 0 , differentiation was initiated by incubating cells in differentiating media, DM2(E) (Zen-Bio Inc.), which consists of DMEM/Ham's F-12 medium containing FBS, L-glutamine, penicillin/streptomycin, insulin, indomethacin, 3-isobutyl-1-methylxanthine with $1 \mu \mathrm{M}$ E and vehicle (DMSO not exceeding 0-1\%). To define the effect of the PF-877423 inhibitor upon the differentiation of primary preadipocytes, cultures were supplemented with 300 nM PF-877423 (in DMSO). Control cells cultured without E. Media were replenished and PF-877423 or vehicle treatment repeated every 2-3 days, except when $11 \beta-H S D 1$ activity was assessed.

\section{Measuring lipid content in human subcutaneous $s-v$ cells}

Lipogenesis in human subcutaneous $\mathrm{s}-\mathrm{v}$ cells was measured as triglyceride accumulation. Cells were carefully washed with PBS and lysed in situ by adding $50 \mu \mathrm{l} /$ well of Hecameg $(10 \%$ solution in water-Calbiochem, Nottingham, UK). After gentle shaking at room temperature for $10 \mathrm{~min}, 200 \mu \mathrm{l}$ triglyceride (Infinity) reagent (Thermo DMA, Louisville, CO, USA) was added to each well. Plates were read after 10-20 min at $500 \mathrm{~nm}$ with correction at $660 \mathrm{~nm}$ (Spectra MAX PLUS Molecular Devices Corporation, Sunnyvale, CA, USA). Results were expressed as optical density (OD) values.

\section{HEK293 and Chubb-S7 11 $\beta-H S D$ assay}

Cells were washed and incubated with $100 \mathrm{nM} \mathrm{F}$ (for dehydrogenase activity) or E (for oxo-reductase activity) with appropriate tritiated tracer $-{ }^{3} \mathrm{H} \mathrm{F}$ (Du Pont, Stevenage, UK) or ${ }^{3} \mathrm{H}$ E $(0 \cdot 02 \mu \mathrm{Ci} /$ reaction; Bujalska et al. 1999). PF-877423 specificity upon $11 \beta-H S D 1$ was carried out with the addition of $100 \mathrm{nM}$ inhibitor to HEK293T1 and HEK293T2 cells $24 \mathrm{~h}$ before and during the enzyme assay. After $3 \mathrm{~h}$ incubation with substrate, media was removed and steroids extracted with $4 \mathrm{ml}$ dichloromethane, evaporated under the air and reconstituted with $70 \mu \mathrm{l}$ dichloromethane, then spotted on silica plates (Sigma-Aldrich). Steroids were separated by thin-layer chromatography in chloroform and ethanol (92:8) and steroid conversion was quantified using a LabLogic AR-200 scanner (LabLogic, Sheffield, UK). Cells were washed and protein concentration was measured using colorimetric 96-well plate assay (Bio-Rad) and total RNA was extracted.

\section{Human subcutaneous $s-v$ cells $11 \beta$-HSD1 assay}

During $11 \beta$-HSD1 activity assessment in human subcutaneous $\mathrm{s}-\mathrm{v}$ cells, the medium was changed to basal medium (BM-1, Zen-Bio Inc.) containing only antibiotics, and cells were cultured for $24 \mathrm{~h}$ in the presence of PF-877423 with or without $0.5 \mu \mathrm{M}$ E. At the end of the incubation, the cortisol signal was quantitatively determined in the $100 \mu \mathrm{l}$ cell supernatant with the Correlate-Enzyme Immunoassay Cortisol kit (Assay Designs Inc. Ann Arbor, MI, USA) following the manufacturers' instructions. Plates were read on a plate reader (Spectra MAX PLUS - Molecular Devices Corporation) at $405 \mathrm{~nm}$, with correction at $580 \mathrm{~nm}$. Activity has been expressed as cortisol production in $\mathrm{pg} / \mathrm{ml}$ per $24 \mathrm{~h}$.

\section{Total RNA extraction and $R T$ reaction}

Total RNA was extracted from cells using TriReagent (Sigma) according to the manufacturer's protocol. Integrity and concentration of RNA were assessed by electrophoresis and spectrophotometry respectively. Reverse transcription was carried out using AMV and random primers at $37^{\circ} \mathrm{C}$ for $1 \mathrm{~h}$. All RT reagents were purchased from Promega.

\section{PCR}

Expression studies were carried out using gene specific primers for human $11 \beta$-HSD1, hexose 6-phosphate dehydrogenase (H6PDH), glucocorticoid receptor $\alpha$ (GR $\alpha$, FABP4), G3PD, glucose transporter 4 (GLUT-4) and PPAR $\gamma$. All primers were designed using primer 3 software (http:// frodo.wi.mit.edu/cgi$\mathrm{bin} /$ primer3/primer3.cgi) and their sequences from $5^{\prime}$ to $3^{\prime}$ are shown in Table 1. Primers for $18 \mathrm{~S}$ as internal control were purchased from Ambion (Quantum RNATM Classic 18S Internal Standard \#1716; Ambion). PCRs were carried out at $95^{\circ} \mathrm{C}$ for $30 \mathrm{~s}, 60^{\circ} \mathrm{C}$ for $30 \mathrm{~s}$ and $72{ }^{\circ} \mathrm{C}$ for $30 \mathrm{~s}$ in $20 \mu \mathrm{l}$ final volume for 30 cycles.

\section{Real-time PCR}

Quantitative mRNA expression levels of $11 \beta-H S D 1, H 6 P D H$, GR $\alpha$, FABP4, G3PD, GLUT-4 and PPAR $\gamma 2$ were measured by real-time PCR using an ABI 7500 system (Perkin-Elmer, Biosystems, Warrington, UK). PCR was performed in $25 \mu \mathrm{l}$ reactions on 96-well plates. Reactions contained TaqMan universal PCR master mix (Applied Biosystems, Foster City, CA, USA), 900 nmol primers, 100-200 nmol TaqMan probe and 25-50 ng cDNA. All reactions were correlated to expression 
Table 1 Primer sequences for various human genes for the PCR

\section{Forward}

Gene
HSD11B1
H6PDH
GR $\alpha$
GLUT-4
PPAR 1
PPAR 2
G3PD
FABP4

ACCAGAGATGCTCCAAGGAA AGAAGCGAGACAGCTTCCAC TCGACCAGTGTTCCAGAGAAC GCCATTGTTATCGGCATTCT TCTCTCCGTAATGGAAGACC GCGATTCCTTCACTGATAC GGAAGACATTGGAGGCAAAA CATCAGTGTGAATGGGGATG
Reverse

ATGCTTCCATTGCTCTGCTT GCTGCTGGGAAAAGAACAAC TTTCGGAACCAACGGGAATTG CTACCСCTGCTGTCTCGAAG GCATTATGAGACATCCCCAC GCATTATGAGACATCCCCAC CCACGGCCACTACATTCTTT ATGCGAACTTCAGTCCAGGT

Primers were designed using Primer3 software (http://frodo.wi.mit.edu/cgi-bin/primer3).

of ribosomal 18S rRNA (provided as a pre-optimized mix; Perkin-Elmer) as an internal reference. All target gene probes were labelled with the fluorescent label FAM and the $18 \mathrm{~S}$ probe with the fluorescent label VIC. Reactions were as follows: $50{ }^{\circ} \mathrm{C}$ for $2 \mathrm{~min}, 95^{\circ} \mathrm{C}$ for $10 \mathrm{~min}$, and then 40 cycles of $95^{\circ} \mathrm{C}$ for $15 \mathrm{~s}$ and $60^{\circ} \mathrm{C}$ for $1 \mathrm{~min}$. Data were analysed according to the manufacturer's guidelines and were obtained as $C_{\mathrm{t}}$ values (the cycle number at which logarithmic PCR plots cross a calculated threshold line) and used to determine $\mathrm{d} C_{\mathrm{t}}$ values $\left(\mathrm{d} C_{\mathrm{t}}=C_{\mathrm{t}}\right.$ of the target gene minus $C_{\mathrm{t}}$ of the internal reference, $18 \mathrm{~S}$ ). Primers and probes for 11 $\beta$-HSD1, H6PDH and G3PD were designed using PrimerExpress 1.0 software (Applied Biosystems). Sequences from $5^{\prime}$ to $3^{\prime}$ are shown in Table 2. Expression assay kits were purchased from Applied Biosystems to measure the gene expression of GR $\alpha$, GLUT-4, PPAR $\gamma 2$ and FABP4.

\section{Statistical analysis}

Where data were normally distributed, unpaired Student's $t$-test was used to compare single treatments with control. If normality tests failed, then non-parametric tests were used. One-way ANOVA on ranks was used to compare multiple treatments (SigmaStat 3·1, Systat Software Inc., Point Richmond, CA, USA). Results were expressed as mean values \pm s.D. or S.E.M. values and a $P$ value of $<0.05$ was accepted as statistically significant. Statistical analysis on real-time PCR data was performed on mean $\Delta C$ t values and not on fold changes.

\section{Results}

Kinetics of PF-877423 upon recombinant $11 \beta$-HSD1 protein

The potency for PF-877423 was strongly affected by the presence of the substrate in the assay buffer (Fig. 1): $K_{i}^{\text {app }}$ values increased at high cortisone concentration, suggesting that the inhibitor behaved as a reversible and competitive inhibitor against cortisone. Fitting the experimental data using equation (2) provided a value of $0 \cdot 2 \pm 0 \cdot 04$ and $333 \cdot 4 \pm$ $109 \cdot 2 \mathrm{nM}$ for the inhibition constant, $K_{i}$, and the apparent Michaelis-Menten constant, $K_{m}$ respectively.

\section{Specificity of PF-877423}

11ß-HSD enzyme assays on HEK293T1 and HEK293T2 cells showed total abolition of dehydrogenase $(12 \cdot 4 \pm 1 \cdot 0$ vs $0 \cdot 2 \pm$ $0 \cdot 01, \%$ cortisol to cortisone conversion, mean \pm s.D. $)$ and oxoreductase $(34 \cdot 7 \pm 0.6$ vs $0 \cdot 4 \pm 0 \cdot 1, \%$ cortisone to cortisol conversion, mean \pm s.D.) activities of $11 \beta$-HSD1 following incubation with $100 \mathrm{nM}$ PF-877423 for $24 \mathrm{~h}$ (Fig. 2A), but PF-877423 had no effect on $11 \beta$-HSD 2 activity $(63 \cdot 6 \pm 4 \cdot 0$ vs $62 \cdot 2 \pm 4 \cdot 4, \%$ cortisol to cortisone conversion, mean \pm s.D., control versus PF-877423 respectively; Fig. 2B). No toxic effects of PF-877423 were observed up to $10 \mu \mathrm{M}$ concentrations using a commercially available assay kit (CellTiter 96 Aqueous, Promega; data not shown).

Table 2 Primer and probe sequences for various human genes for the real-time PCR

Forward

\section{Gene}

HSD11B1 AGGAAAGCTCATGGGAGGACTAG

$\mathrm{H6PDH}$ GGGCCTATGGAACCTCCAA

PPAR 2 AGAAGAAGGCGGCGTTGTC

G3PD CCATCAGTTCATCGGCAAGAT
Reverse

ATGGTGAATATCATCATGAA AAAGATTC

GACCCACGTTTCTCACTGAC TCT

TCAGGTTGAGGCCACCATC

TCGTCTACCCCCTTAATAAG AGATATC
Probe

CATGCTCATTCTCAACCACATCA CCAACA CCGTGGCGCTACTCATGGACAC A AGGGGCCACCACAGACTTGCAC AT AGGGCCATCTGAAGGCAAACGC C

Primers and probes were designed using PrimerExpress software (Applied Biosystems, UK). 


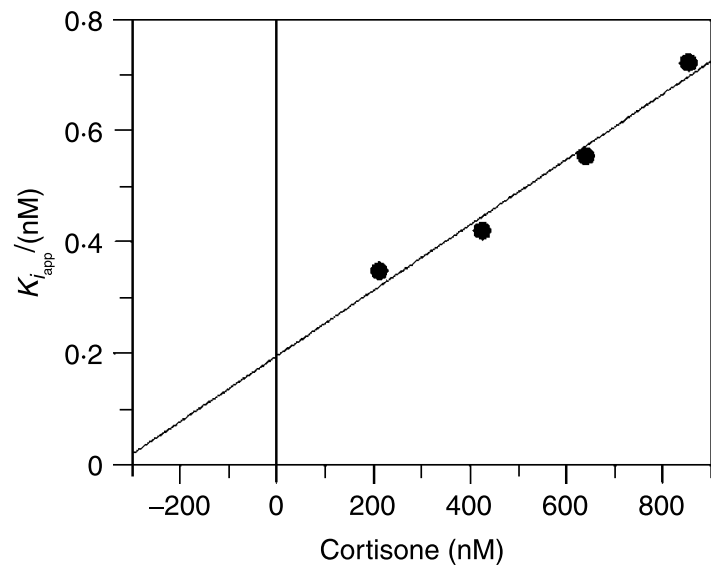

Figure 1 Effect of cortisone concentration upon the apparent inhibition constant $K i_{\text {app }}$ of the inhibitor PF-877423: a value for the true inhibition constant $K_{i}(0 \cdot 2 \pm 0 \cdot 04 \mathrm{nM})$ and the MichaelisMenten constant $K_{m}(333 \cdot 4 \pm 109 \cdot 2 \mathrm{nM})$ is calculated by fitting the experimental data using equation (2).

\section{Characterisation of chub-S7 cells}

At confluence (day 0), Chub-S7 cells did not accumulate lipid droplets (Fig. 3A); however, they readily underwent adipogenesis (shown as oil red $\mathrm{O}$ staining) when cultured for 21 days in chemically-defined, serum-free media (166 nM insulin, $1 \mu \mathrm{M}$ $\operatorname{PPAR} \gamma$ agonist and $1 \mu \mathrm{M} \mathrm{F}$; Fig. 3B). As demonstrated by conventional PCR, confluent undifferentiated Chub-S7 cells expressed GR $\alpha$ H6PDH and PPAR $\gamma 1$ mRNA but not
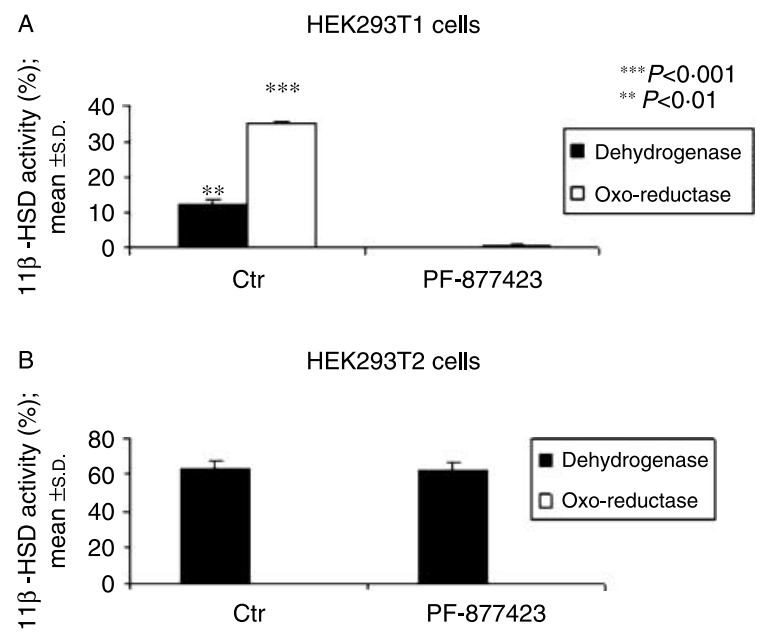

Figure 2 (A) PF-877423 inhibits $11 \beta$-HSD1 enzyme activity (dehydrogenase: $12 \cdot 4 \pm 1 \cdot 0$ vs $0 \cdot 2 \pm 0 \cdot 01$, \% cortisol to cortisone conversion, and oxo-reductase: $34 \cdot 7 \pm 0 \cdot 6$ vs $0 \cdot 4 \pm 0 \cdot 1, \%$ cortisone to cortisol conversion, mean \pm s.D.) as measured in HEK293T1 (HEK293 cells stably transfected with human $11 \beta$-HSD type 1 cDNA), $n=3$ but not (B) $11 \beta$-HSD2 enzyme activity $(63 \cdot 6 \pm 4 \cdot 0$ vs $62 \cdot 2 \pm 4 \cdot 4, \%$ cortisol to cortisone conversion, mean \pm s.D., control versus PF-9 $=877423$ respectively) as measured in HEK293T2 (cells stably transfected with human $11 \beta-\mathrm{HSD}$ type $2 \mathrm{cDNA}), n=3$.

$P$ values: ${ }^{* *} P<0 \cdot 01,{ }^{* * *} P<0 \cdot 001$.
$11 \beta-H S D 1$, PPAR $\gamma 2$, GLUT-4, G3PD or FABP4 mRNA (Fig. 3C). In the differentiated Chub-S7 cells, increased expression of adipogenic markers including G3PD and FABP4 was observed. This process resulted in an increase in 11 $\beta-H S D 1$, GLUT-4 and PPAR $\gamma 2$ mRNA levels (Fig. 3D).

Across differentiation, 11 $\beta$-HSD1 oxo-reductase activity increased significantly; from nil on day 0 to $0 \cdot 4 \pm 0 \cdot 2$ on day $3,5 \cdot 3 \pm 0 \cdot 7$ on day $5,8 \cdot 4 \pm 0 \cdot 14$ on day $7,10 \cdot 5 \pm 1 \cdot 9$ on day 9 and $5.9 \pm 1.9$ on day $16(\mathrm{pmol} / \mathrm{mg}$ per h, mean \pm s.D., $n=7$, all $P<0 \cdot 01$ versus previous time point; Fig. 4A). Conventional PCR findings were endorsed and quantified by real-time PCR. Expression of $11 \beta-H S D 1$ mRNA increased $2 \cdot 9$-fold on day 5 , 3.6-fold on day 7, 3.4-fold on day $9(P<0 \cdot 01)$ and $38 \cdot 1$-fold on day $16(P<0 \cdot 001)$ when compared with day $3, n=4$ (Fig. 4B).

We observed a transient increase in H6PDH mRNA levels (11 $\beta$-HSD1 co-factor provider) $-2 \cdot 9$-fold on day $3,3 \cdot 5$-fold on day $5,3 \cdot 7$-fold on day $7,3 \cdot 4$-fold on day 9 and $0 \cdot 6$-fold on day 16 versus day $0, P<0 \cdot 01$ (Fig. $4 \mathrm{C}$ ) - but there was no significant change in GR $\alpha$ mRNA during Chub-S7 differentiation (Fig. 4D).

Significant increases in differentiation markers FABP4 (2-fold on day $5(P<0 \cdot 01), 38$-fold on day 7,142 -fold on day 9 and 870 -fold on day 16 versus day $3, P<0 \cdot 001)$ and G3PD $(4 \cdot 5$-fold on day $7(P<0 \cdot 01), 22$-fold on day 9 and 380 -fold on day 16 versus day $5, P<0 \cdot 001$ ) were also observed (Fig. 5A and B respectively). When compared with day 7 , the expression of adipocyte-specific genes including GLUT-4 and PPAR $\gamma 2$ also increased $-2 \cdot 1$-fold on day 9 and $9 \cdot 8$-fold on day $16, P<0 \cdot 01$ (GLUT-4) and $1 \cdot 3$-fold on day 7 and $2 \cdot 2$-fold on day 16 , $P<0.01$ (PPAR $\gamma 2$; Fig. 5C and D respectively).

Glucocorticoid metabolism and adipogenesis in Chub-S7 cells incubated with PF-877423

Chub-S7 cells differentiated for 10 days with $500 \mathrm{nM}$ cortisone showed increased 11ß-HSD1 oxo-reductase activity: $14 \cdot 6 \pm 2 \cdot 3$ (E) versus $3 \cdot 4 \pm 1 \cdot 3$ (control), $\mathrm{pmol} / \mathrm{mg}$ per $\mathrm{h}$ mean \pm s.E.M., $P<0.001$ (Fig. 6A), and mRNA expression (14-1-fold versus control; Fig. 6B). Co-incubation with $100 \mathrm{nM}$ PF-877423 abolished this effect: $14 \cdot 6 \pm 2 \cdot 3$ (E) versus $1 \cdot 3 \pm 1 \cdot 1(\mathrm{E}+\mathrm{PF}-877423)$ vs $0 \cdot 6 \pm 0 \cdot 5(\mathrm{PF}-877423)$ $\mathrm{pmol} / \mathrm{mg}$ per h, mean \pm s.E.M. (Fig. $6 \mathrm{~A}$ ) and $14 \cdot 1$-fold (E) versus 1-2-fold (E+PF-877423), 11 $\beta$-HSD1 activity and mRNA respectively (Fig. 6B). Differentiated Chub-S7 cells with $\mathrm{E}$ showed increased expression of the adipogenic markers FABP4 (312-fold versus control, $P<0 \cdot 001)$ and G3PD (47-fold versus control, $P<0 \cdot 001$ ) - an effect that was completely abolished by co-incubation with PF-877423 (1.3and $0 \cdot 7$-fold, FABP4 and G3PD respectively; Fig. 6C and D). The change in adipogenesis following incubation with the $11 \beta$-HSD1-specific inhibitor was confirmed visually through staining the cells with oil red $\mathrm{O}$ after 21 days of differentiation. A marked increase in the number of red-stained cells was observed in cells differentiated with $\mathrm{E}$ or $\mathrm{F}$ but not in the presence of PF-877423 (Fig. 6E). 
A

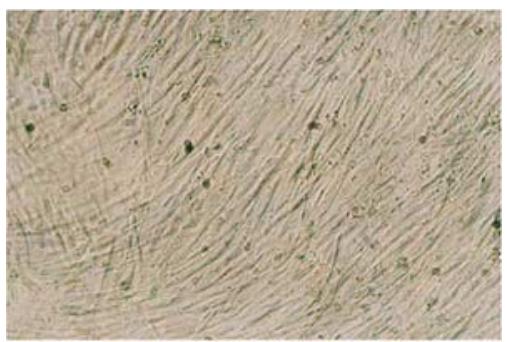

Day 0 - oil red O staining

\section{C}

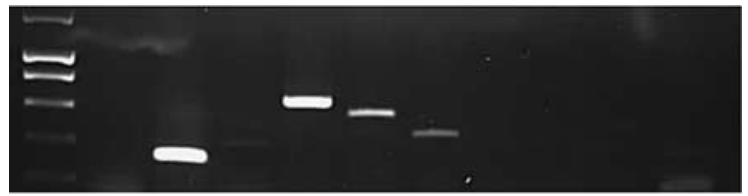

DNA Neg Ctr 18S 11ß-HSDI GRa H6PDH PPARg1 PPARg2 GLUT4 G3PD FABP4 ladder
B

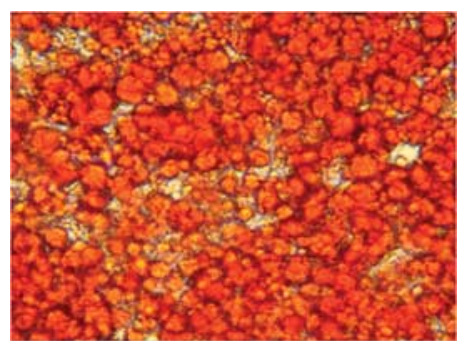

Day 21 - oil red O staining
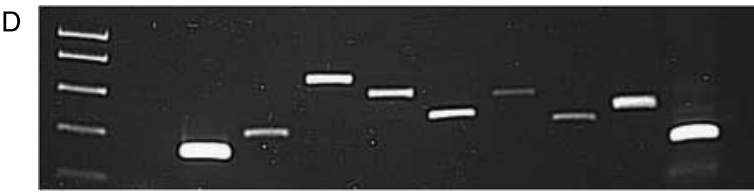

DNA Neg Ctr $18 \mathrm{~S}$ 11ß-HSDI GRa H6PDH PPARg1 PPARg2 GLUT4 G3PD FABP4 ladder

Figure 3 Oil red O staining in (A) confluent Chub-S7 cells (day 0) and (B) differentiated Chub-S7 (day 21). RT-PCR analysis (30 cycles) of nine gene expressions in (C) confluent Chub-S7 cells and (D) in differentiated Chub-S7 cells.

Human subcutaneous $s-v$ cells differentiation

Human subcutaneous $s-\mathrm{v}$ cells differentiated with $\mathrm{E}+\mathrm{PF}-$ 877423 had significantly lower $11 \beta-H S D 1$ oxo-reductase activity compared with cells differentiated with $\mathrm{E}$ at any time point studied (day 6: $154 \pm 8$ vs $5387 \pm 182$; day 9: $128 \pm 1$ vs 5489 \pm 230 ; day 14: $174 \pm 18$ vs $4041 \pm 106$; day $20: 409 \pm 27$ vs $10443 \pm 78$; day $22: 330 \pm 7$ vs $11218 \pm 193 \mathrm{pg} / \mathrm{ml}$ per $24 \mathrm{~h}$, mean \pm s.D., $P<0 \cdot 001, n=3, \mathrm{E}-$ or $\mathrm{E}+\mathrm{PF}-877423$ treated respectively (Fig. 7A)). Lipid content in cells differentiated with $\mathrm{E}$ and PF-877423 was significantly lower than in cells differentiated with $\mathrm{E}$ only and similar to undifferentiated cells (day $16,0 \cdot 25 \pm 0 \cdot 03$ vs $0 \cdot 20 \pm 0 \cdot 01$; day $20,0 \cdot 3 \pm 0 \cdot 02$ vs $0 \cdot 20 \pm 0 \cdot 01$; day $22,0 \cdot 27 \pm 0 \cdot 01$ vs $0 \cdot 19 \pm 0 \cdot 01$; OD (500/ $660 \mathrm{~nm})$; mean \pm s.D., $P<0 \cdot 01, n=3, \mathrm{E}-$ or $\mathrm{E}+\mathrm{PF}-877423$ treated respectively; Fig. 7B).

\section{Discussion}

Numerous studies (Hauner et al. 1989, Gregoire et al. 1991, Wolf 1999), including our own (Bujalska et al. 1999, 2002b), have

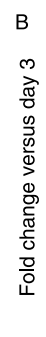

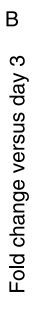
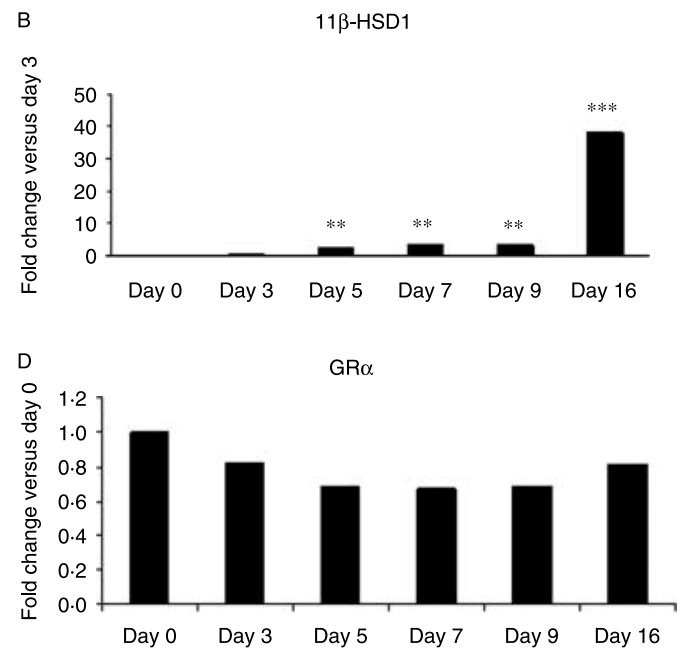
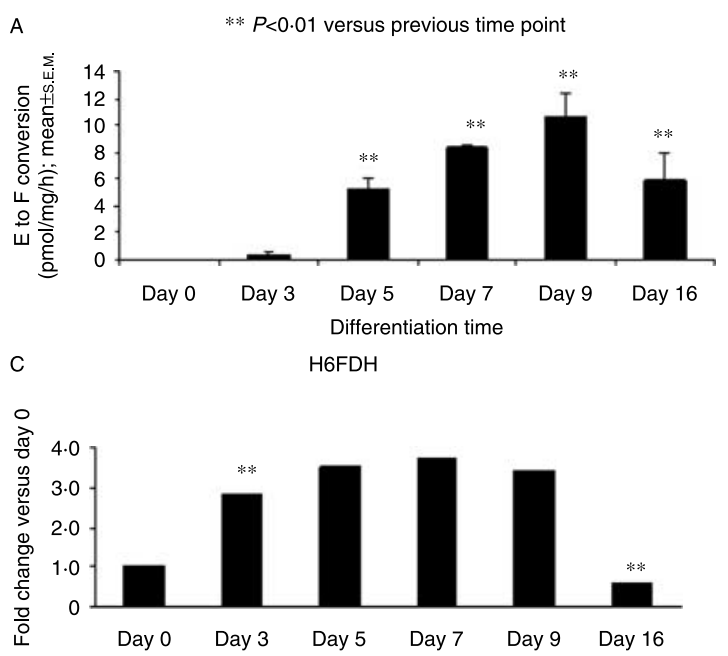

Figure 4 (A) 11ß-HSD1 oxo-reductase activity (cortisone to cortisol conversion); nil on day 0 to $0 \cdot 4 \pm 0 \cdot 2$ on day 3 $5 \cdot 3 \pm 0.7$ on day $5,8 \cdot 4 \pm 0 \cdot 14$ on day $7,10.5 \pm 1.9$ on day 9 and $5.9 \pm 1.9$ on day $16, \mathrm{pmol} / \mathrm{mg}$ per h, mean \pm s.D. versus

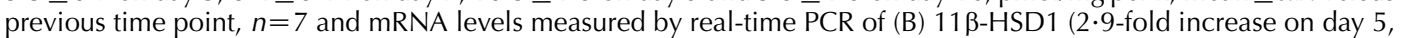
$3 \cdot 6$-fold on day $7,3 \cdot 4$-fold on day 9 and $38 \cdot 1$-fold on day 16 when compared with day 3 ). (C) H6PDH increased 2.9fold on day $3,3 \cdot 5$-fold on day $5,3 \cdot 7$-fold on day $7,3 \cdot 4$-fold on day 9 and $0 \cdot 6$-fold on day 16 versus day 0 and (D) GR $\alpha$ (no significant change) across Chub-S7 differentiation, $n=4$. $P$ values: ${ }^{* *} P<0 \cdot 01,{ }^{* * *} P<0 \cdot 001$. 
FABP4

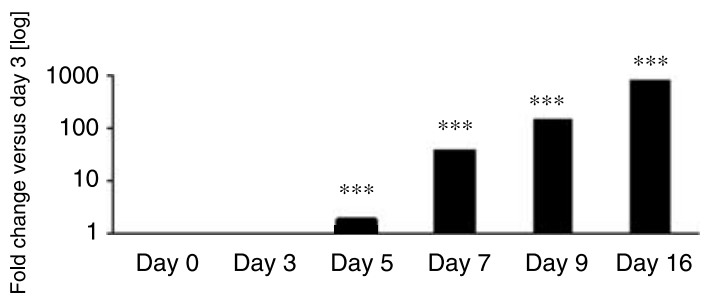

C

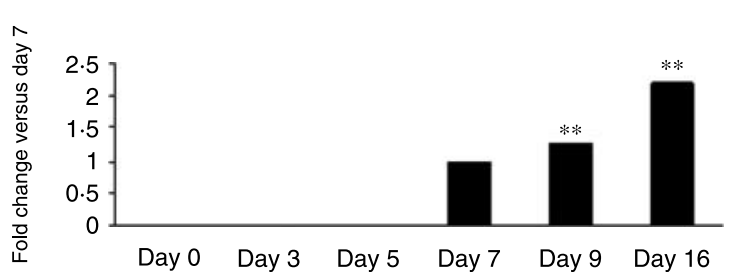

B

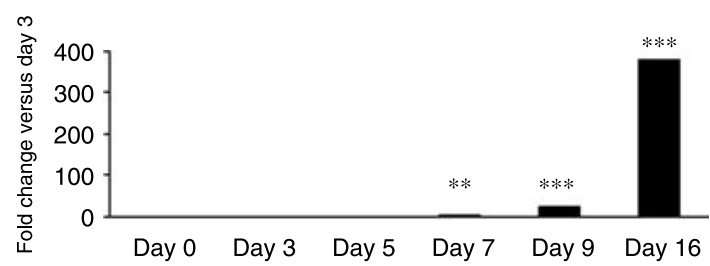

D

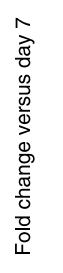

G3PD

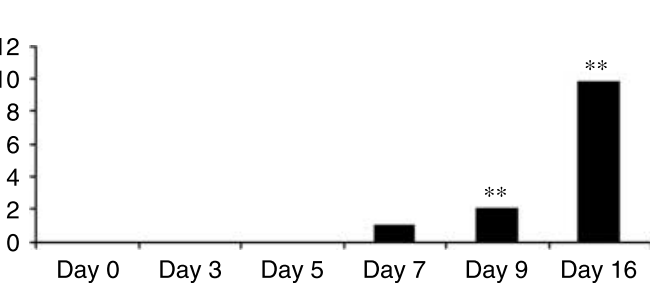

Figure 5 Gene expression analysed by real-time PCR of adipogenic markers; (A) FABP4: (log scale) 2-fold increase on day 5 , 38-fold on day 7, 142-fold on day 9 and 870-fold on day 16 versus day 3; (B) G3PD: 4.5-fold on day 7, 22-fold on day 9 and 380-fold on day 16 versus day 5; (C) PPAR 2 : $1 \cdot 3$-fold on day 9 and $2 \cdot 2$-fold on day 16 versus day 7 ; and (D) GLUT-4: $2 \cdot 1$-fold on day 9 and $9 \cdot 8$-fold on day 16 versus day 7 across Chub-S7 cell differentiation. $P$ values: ${ }^{* *} P<0 \cdot 01,{ }^{* * *} P<0 \cdot 001$.

defined the permissive role of GCs in inducing adipocyte differentiation. Here, we extend those observations to a novel transformed human adipocyte cell line that should greatly enhance in vitro human-based adipocyte research studies. Within 5 days of incubation in chemically defined media comprising insulin, PPAR $\gamma$ agonist and glucocorticoid, impressive differentiation was observed in Chub-S7 cells as assessed by markers including FABP4, G3PD and adipocyte-specific genes such as GLUT-4 and PPAR $\gamma 2$. Adipogenesis was an ongoing process up to 16 days in culture with intracellular lipid stores confirmed by oil red $\mathrm{O}$ staining. No significant changes were observed in GR $\alpha$ expression during this differentiation phase; earlier studies had reported increased GR expression in omental versus subcutaneous adipose tissue and had argued that this may be the one factor explaining the predilection of glucocorticoids for visceral obesity (Bronnegard et al. 1990). However, more recently our array and real-time PCR analyses failed to demonstrate any difference in GR expression between human omental and subcutaneous preadipocytes (Bujalska et al. 2006) and adipose tissue (unpublished data). Together with the data in this study, it seems unlikely that changes in GR expression per se are important in the adipogenesis process.

At a pre-receptor level our group has focussed on the role of $11 \beta-H S D 1$ and the regeneration of cortisol from inactive cortisone in human adipose tissue. Previously we have demonstrated increased expression of $11 \beta$-HSD1 in omental compared with subcutaneous depots (Bujalska et al. 1997b), and importantly a switch in the directionality of enzyme activity from predominant dehydrogenase to oxo-reductase (Bujalska et al. 2002a), probably as a result of induction of the NADPH donor source for $11 \beta-H S D 1$ within the endoplasmic reticulum (ER) lumen, H6PDH (Ozols 1993). In support of these observations, in this study, the rise in H6PDH mRNA levels probably explained the increase in $11 \beta$-HSD1-mediated oxoreductase activity between days 3 and 9 in addition to an increase in 11 $\beta$-HSD1 mRNA levels. Furthermore, decreased H6PDH mRNA expression seen on day 16 might account for the decline in $11 \beta-H S D 1$ oxo-reductase activity despite high mRNA. The impressive increase in 11ß-HSD1 expression across adipocyte differentiation has been noted recently in mouse 3T3-L1 cells (Kim et al. 2007), as it has been done in other differentiating cell systems including osteoblasts (Eijken et al. 2005). In both cases cells have been incubated with glucocorticoids that themselves positively regulate $11 \beta-H S D 1$ (Bujalska et al. 1997b); it is not possible from these or previous data sets to conclude whether or not the increased $11 \beta-H S D 1$ expression is glucocorticoid mediated or a manifestation of the differentiation process per se.

Nevertheless, $11 \beta$-HSD1 expression, resulting in a functionally active oxo-reductase, was clearly linked to the differentiation phenotype. Incubation of Chub-S7 cells with inactive steroid, cortisone, induced a degree of adipocyte differentiation similar to that observed with cortisol. This could be explained on the basis of 11 $\beta$-HSD1-mediated oxo-reductase activity with a $K_{m}$ for cortisone in Chubb-S7 cells of $100 \mathrm{nM}$ which is similar to the reports in other $11 \beta$-HSD1-expressing cell systems (Monder \& Lakshmi 1989, Ricketts et al. 1998) including studies on the recombinant enzyme $\left(K_{\mathrm{m}}=333 \mathrm{nM}\right.$; Walker et al. 2001, Shafqat et al. 2003). Evaluation of the competitive $11 \beta$-HSD1 inhibitor, PF-877423, indicated selectivity for the type $111 \beta$-HSD isoform with a $K_{i}=0 \cdot 2 \mathrm{nM}$ in the recombinant assay and $\mathrm{IC} 50 \sim 5 \mathrm{nM}$ in Chubb-S7 cells. Selectivity of the inhibitor towards $11 \beta$-HSD1 isoform but not $11 \beta-H S D 2$ is crucial as patients with impairment in the latter are presented with severe hypertension, (White et al. 1997). 
A

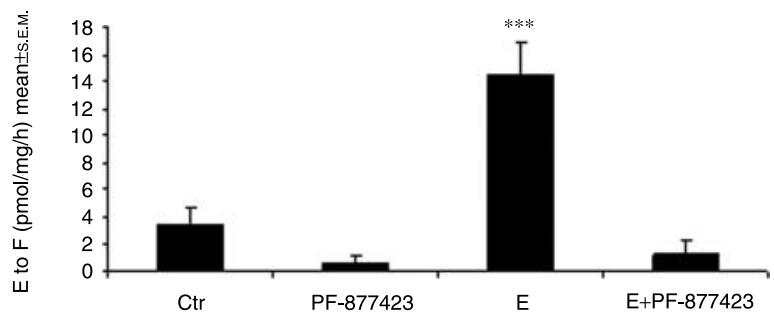

C

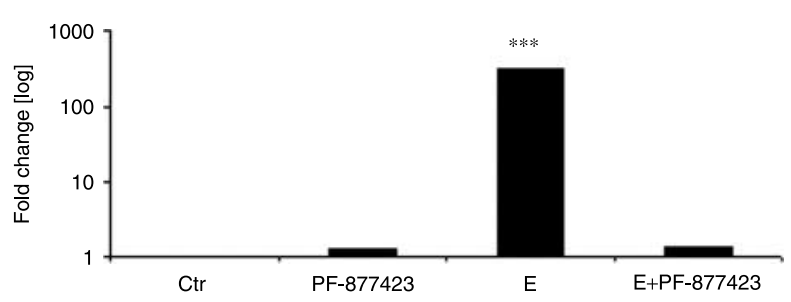

B

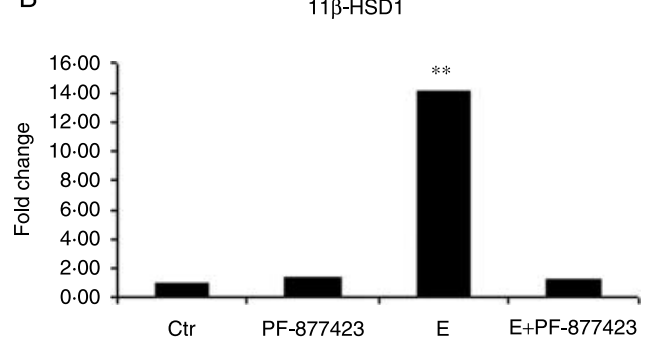

D

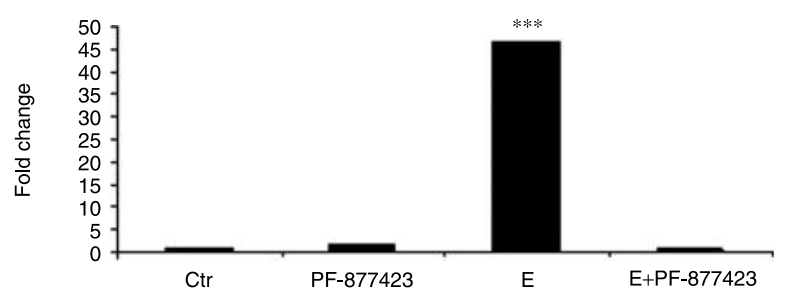

E Ctr E E+PF-877423

F

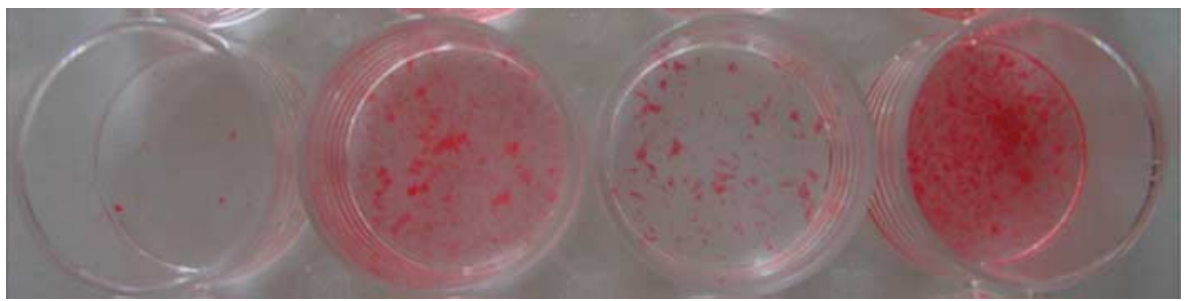

Figure 6 Chub-S7 cells differentiated with $0.5 \mu \mathrm{M} \mathrm{E}$ and with or without the selective $11 \beta-H S D 1$ inhibitor PF-877423 at $100 \mathrm{nM}$. All experiments were carried out on differentiated cells on day 10, $n=3$. (A) 11 $\beta$-HSD1 oxo-reductase activity (cortisone to cortisol conversion): $14 \cdot 6 \pm 2 \cdot 4$ (E) versus $1 \cdot 2 \pm 1 \cdot 1$ (E + PF-877423) vs $3 \cdot 4 \pm 1 \cdot 3$ (control), pmol/mg per $\mathrm{h}$ mean \pm s.E.M., $P<0 \cdot 001$, (B) $11 \beta$-HSD1 mRNA expression and adipogenic markers (C) FABP4, (D) G3PD (log scale, $P<0.001$ and $P<0 \cdot 001$ respectively) and (E) Chub-S7 cells differentiated for 21 days and stained with oil red O; 1) control: $166 \mathrm{nM}$ insulin, PPAR $\gamma$ agonist, $100 \mathrm{nM}$ PF-877423, 2) $0.5 \mu \mathrm{M} \mathrm{E}$, 3) $0.5 \mu \mathrm{M} \mathrm{E}+100 \mathrm{nM}$ PF-877423 and 4) positive control (differentiation with $0.5 \mu \mathrm{M} \mathrm{F}$ ). $P$ values: ${ }^{* *} P<0 \cdot 01,{ }^{* * *} P<0 \cdot 001$.

PF-877423 selectivity was undertaken using a transformed cell line expressing human $11 \beta-H S D 2$ enzyme where no inhibitory effect was observed. Incubation of cells with $100 \mathrm{nM}$ PF-877423 completely abolished the cortisone induction of FABP4, G3PDH and 11 $\beta-$ HSD1 itself in Chubb-S7 cells. We also demonstrated that the transformed cell line data were consistent with data in primary human subcutaneous preadipocytes. While incubation with cortisone yielded a less impressive effect on adipogenesis in human subcutaneous preadipocytes when compared with Chubb-S7 cells (this might reflect a more advanced adipogenic lineage of primary cultures), inhibition of $11 \beta-H S D 1$ activity nevertheless reduced the ability of human subcutaneous preadipocytes to differentiate and accumulate lipid.

Whilst the cell line that we have used is subcutaneous in origin and the expression of $11 \beta-H S D 1$ is higher in omental human preadipocytes (Bujalska et al. 1997b) and therefore we predict that the impact upon omental cells would be more pronounced. We anticipate that this would not lead to preferential loss of subcutaneous fat. Unfortunately, omental cell lines are not available for study and in vivo human clinical studies have not been performed.

Previously, non-selective 11ß-HSD inhibitors have been shown to diminish human adipocyte differentiation in vitro (Bujalska et al. 1999) and increase insulin sensitivity in man (Walker et al. 1995), but a lack of isozyme selectivity can cause water retention and hypertension. Since then, patents have been filed on compounds that report to be selective $11 \beta-H S D 1$ inhibitors. An aryl sulphonamide derivative has been shown to reduce insulin levels and improve glucose tolerance when administered to rodents for 7 days (Alberts et al. 2002). Similar data have been reported for an adamantyl triazole that also reduced body weight and the progression of atherosclerosis in mice (Hermanowski-Vosatka et al. 2005). Transgenic mouse models have established $11 \beta$-HSD1 as a novel therapeutic target in this regard; global deletion of $11 \beta-H S D 1$ results in improved 
A

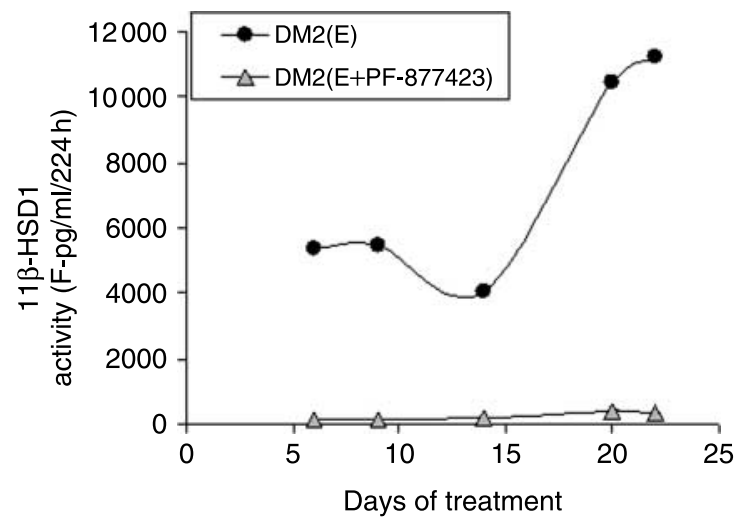

B

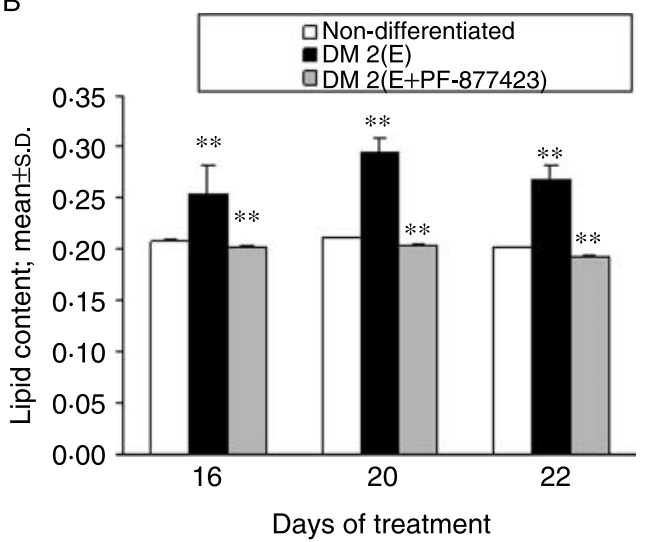

Figure 7 (A) Effect of chronic exposure to the selective 11 $\beta$-HSD1 inhibitor PF-877423 on subcutaneous s-v cells. 11 $\beta$-HSD1 enzyme inhibition by $300 \mathrm{nM}$ PF-877423 measured as the production of cortisol (day 6: $154 \pm 8$ vs $5387 \pm 182$; day 9: $128 \pm 1$ vs $5489 \pm 230$; day 14: $174 \pm 18$ vs $4041 \pm 106$; day $20: 409 \pm 27$ vs $10443 \pm 78$; day $22: 330 \pm 7$ vs $11218 \pm 193 \mathrm{pg} / \mathrm{ml}$ per $24 \mathrm{~h}$, mean \pm s.D., $P<0 \cdot 001, n=3, \mathrm{E}-$ or $\mathrm{E}+\mathrm{PF}-877423$-treated respectively). (B) Inhibition of lipid accumulation by $300 \mathrm{nM}$ PF-877423 in subcutaneous stromal-vascular cells (day 16: $0 \cdot 25 \pm 0 \cdot 03$ vs $0 \cdot 20 \pm 0 \cdot 01$; day 20: $0 \cdot 3 \pm 0 \cdot 02$ vs $0 \cdot 20 \pm 0 \cdot 01$; day $22: 0 \cdot 27 \pm 0 \cdot 01$ vs $0 \cdot 19 \pm 0 \cdot 01 ;$ OD $(500 / 660 \mathrm{~nm}), n=3, \bar{E}-$ or E+PF-877423-treated respectively), $P$ values: ${ }^{* * P}<00 \cdot 01, * * * P<0 \cdot 001$.

glucose tolerance through reduced gluconeogenesis and hepatic glucose output (Kotelevtsev et al. 1997, Morton et al. 2001), while targeted overexpression of $11 \beta$-HSD1 in adipose tissue recapitulates features of the MS including central adiposity (Masuzaki et al. 2001). In the liver of $\mathrm{db} / \mathrm{db}$ mice (a model of type 2 diabetes), GR and 11ß-HSD1 mRNA expression positively correlated with blood insulin and glucose (Liu et al. 2005). Inhibition of GR and $11 \beta-H S D 1$ expression either with GR antagonist (RU486; Liu et al. 2005) or by chronic activation of liver X receptor (Liu et al. 2006) attenuated the phenotype of type 2 diabetes in mice.

In humans, the situation is less clear with regard to a role for $11 \beta-H S D 1$ in the pathogenesis of MS. Some authors have argued for a primary overexpression of $11 \beta-H S D 1$ in affected patients akin to that observed in some animal models (Paulmyer-Lacroix et al. 2002, Rask et al. 2002). However, while the expression of $11 \beta$-HSD1 might be increased, at least in subcutaneous adipose tissue in obese patients with MS and type 2 diabetes (Tomlinson et al. 2002, Alberti et al. 2007), no such increase was observed in omental adipose tissue. Furthermore, based on urinary cortisol/cortisone metabolite ratios and plasma cortisol generation curves following oral cortisone acetate that primarily reflects hepatic $11 \beta-H S D 1$ expression, a reduction, not an increase, in 11 $\beta-$ HSD1 expression was observed at least in subjects with simple obesity (Stewart et al. 1999, Tomlinson et al. 2004). We have argued that obesity is not primarily a state of $11 \beta-H S D 1$ overexpression, but that the fall in hepatic $11 \beta$-HSD1 activity with increased visceral adiposity might serve as a protective mechanism to offset hepatic glucose output and further adiposity (Valsamakis et al. 2004). Failure of such a switch off in $11 \beta$-HSD1 expression might be a factor that determines the onset and persistence of hyperglycaemia in obese patients with type 2 diabetes mellitus (Valsamakis et al. 2004). Further studies are indicated to define the exact role of $11 \beta-H S D 1$ in the pathophysiology of human MS. Irrespective of the outcome of these studies, selective inhibitors such as PF-877423 offer a real advance in the prevention and treatment of diabetes in subjects with obesity with the potential added benefit of inhibiting adipocyte differentiation. A reduction in adipogenesis specifically within omental depots is likely to further improve the metabolic phenotype of these patients. Clinical studies characterising a novel, potent $\left(K_{i} \quad 0 \cdot 2 \mathrm{nM}\right)$ and fully selective $11 \beta-$ HSD1 inhibitor preventing lipogenesis in vitro will further our understanding of the role of local glucocorticoid metabolism in human adipose tissue.

\section{Acknowledgements}

The work was supported by a Wellcome Trust Programme Grant (Ref No 066357) and MRC Grant (G0502165). The authors thank Jeff Zhu for providing the human $11 \beta$-HSD1 recombinant protein.

\section{Disclosure}

I J B, L L G, J W T and C D declare no conflict of interest. J E, A N F and P A R are employed by Pfizer. P M S is on the advisory board for Pfizer Global R\&D.

\section{References}

Alberti L, Girola A, Gilardini L, Conti A, Cattaldo S, Micheletto G \& Invitti C 2007 Type 2 diabetes and metabolic syndrome are associated with increased expression of $11 \beta$-hydroxysteroid dehydrogenase 1 in obese subjects. International Journal of Obesity 31 1826-1831. 
Alberts P, Engblom L, Edling N, Forsgren M, Klingstrom G, Larsson C, Ronquist-Nii Y, Ohman B \& Abrahmsen L 2002 Selective inhibition of $11 \beta$-hydroxysteroid dehydrogenase type 1 decreases blood glucose concentrations in hyperglycaemic mice. Diabetologia 45 1528-1532.

Bronnegard M, Arner P, Hellstrom L, Akner G \& Gustafsson JA 1990 Glucocorticoid receptor messenger ribonucleic acid in different regions of human adipose tissue. Endocrinology 127 1689-1696.

Bujalska I, Shimojo M, Howie A \& Stewart PM 1997a Human 11ßhydroxysteroid dehydrogenase: studies on the stably transfected isoforms and localization of the type 2 isozyme within renal tissue. Steroids 62 77-82.

Bujalska IJ, Kumar S \& Stewart PM 1997b Does central obesity reflect 'Cushing's disease of the omentum'? Lancet 349 1210-1213.

Bujalska IJ, Kumar S, Hewison M \& Stewart PM 1999 Differentiation of adipose stromal cells: the roles of glucocorticoids and $11 \beta$-hydroxysteroid dehydrogenase. Endocrinology 140 3188-3196.

Bujalska IJ, Walker EA, Hewison M \& Stewart PM 2002a A switch in dehydrogenase to reductase activity of $11 \beta$-hydroxysteroid dehydrogenase type 1 upon differentiation of human omental adipose stromal cells. Journal of Clinical Endocrinology and Metabolism 87 1205-1210.

Bujalska IJ, Walker EA, Tomlinson JW, Hewison M \& Stewart PM $2002 b$ $11 \beta$-hydroxysteroid dehydrogenase type 1 in differentiating omental human preadipocytes: from de-activation to generation of cortisol. Endocrine Research 28 449-461.

Bujalska IJ, Quinkler M, Tomlinson JW, Montague CT, Smith DM \& Stewart PM 2006 Expression profiling of 11ß-hydroxysteroid dehydrogenase type-1 and glucocorticoid-target genes in subcutaneous and omental human preadipocytes. Journal of Molecular Endocrinology 37 327-340.

Darimont C, Zbinden I, Avanti O, Leone-Vautravers P, Giusti V, Burckhardt P, Pfeifer AM \& Mace K 2003 Reconstitution of telomerase activity combined with HPV-E7 expression allow human preadipocytes to preserve their differentiation capacity after immortalization. Cell Death and Differentiation 10 1025-1031.

De PR, Green A, Kao MY \& Olefsky JM 1981 Effects of prednisolone and dexamethasone in vivo and in vitro: studies of insulin binding, deoxyglucose uptake and glucose oxidation in rat adipocytes. Diabetologia 21 149-153.

Eijken M, Hewison M, Cooper MS, de Jong FH, Chiba H, Stewart PM, Uitterlinden AG, Pols HA \& van Leeuwen JP 2005 11ß-Hydroxysteroid dehydrogenase expression and glucocorticoid synthesis are directed by a molecular switch during osteoblast differentiation. Molecular Endocrinology 19 621-631.

Fraser R, Ingram MC, Anderson NH, Morrison C, Davies E \& Connell JM 1999 Cortisol effects on body mass, blood pressure, and cholesterol in the general population. Hypertension 33 1364-1368.

Gregoire F, Genart C, Hauser N \& Remacle C 1991 Glucocorticoids induce a drastic inhibition of proliferation and stimulate differentiation of adult rat fat cell precursors. Experimental Cell Research 196 270-278.

Hauner H, Schmid P \& Pfeiffer EF 1987 Glucocorticoids and insulin promote the differentiation of human adipocyte precursor cells into fat cells. Journal of Clinical Endocrinology and Metabolism 64 832-835.

Hauner H, Entenmann G, Wabitsch M, Gaillard D, Ailhaud G, Negrel R \& Pfeiffer EF 1989 Promoting effect of glucocorticoids on the differentiation of human adipocyte precursor cells cultured in a chemically defined medium. Journal of Clinical Investigation 84 1663-1670.

Hermanowski-Vosatka A, Balkovec JM, Cheng K, Chen HY, Hernandez M, Koo GC, Le Grand CB, Li Z, Metzger JM, Mundt SS et al. 2005 $11 \beta-H S D 1$ inhibition ameliorates metabolic syndrome and prevents progression of atherosclerosis in mice. Journal of Experimental Medicine $202517-527$.

Hotamisligil GS, Johnson RS, Distel RJ, Ellis R, Papaioannou VE \& Spiegelman BM 1996 Uncoupling of obesity from insulin resistance through a targeted mutation in aP2, the adipocyte fatty acid binding protein. Science 274 1377-1379.

Kershaw EE, Morton NM, Dhillon H, Ramage L, Seckl JR \& Flier JS 2005 Adipocyte-specific glucocorticoid inactivation protects against dietinduced obesity. Diabetes 54 1023-1031.
Kim J, Temple KA, Jones SA, Meredith KN, Basko JL \& Brady MJ 2007 Differential modulation of 3T3-L1 adipogenesis mediated by $11 \beta-$ hydroxysteroid dehydrogenase-1 levels. Journal of Biological Chemistry 282 11038-11046.

Kotelevtsev Y, Holmes MC, Burchell A, Houston PM, Schmoll D, Jamieson P, Best R, Brown R, Edwards CR, Seckl JR et al. 1997 11ß-Hydroxysteroid dehydrogenase type 1 knockout mice show attenuated glucocorticoidinducible responses and resist hyperglycemia on obesity or stress. PNAS 94 14924-14929.

Liu Y, Nakagawa Y, Wang Y, Sakurai R, Tripathi PV, Lutfy K \& Friedman TC 2005 Increased glucocorticoid receptor and $11 \beta$-hydroxysteroid dehydrogenase type 1 expression in hepatocytes may contribute to the phenotype of type 2 diabetes in $\mathrm{db} / \mathrm{db}$ mice. Diabetes $\mathbf{5 4} 32-40$.

Liu Y, Yan C, Wang Y, Nakagawa Y, Nerio N, Anghel A, Lutfy K \& Friedman TC 2006 Liver X receptor agonist T0901317 inhibition of glucocorticoid receptor expression in hepatocytes may contribute to the amelioration of diabetic syndrome in $\mathrm{db} / \mathrm{db}$ mice. Endocrinology 147 5061-5068.

Masuzaki H, Paterson J, Shinyama H, Morton NM, Mullins JJ, Seckl JR \& Flier JS 2001 A transgenic model of visceral obesity and the metabolic syndrome. Science 294 2166-2170.

Masuzaki H, Yamamoto H, Kenyon CJ, Elmquist JK, Morton NM, Paterson JM, Shinyama H, Sharp MG, Fleming S, Mullins JJ et al. 2003 Transgenic amplification of glucocorticoid action in adipose tissue causes high blood pressure in mice. Journal of Clinical Investigation 112 83-90.

Monder C \& Lakshmi V 1989 Evidence for kinetically distinct forms of corticosteroid $11 \beta$-dehydrogenase in rat liver microsomes. Journal of Steroid Biochemistry 32 77-83.

Morrison JF 1969 Kinetics of the reversible inhibition of enzyme-catalysed reactions by tight-binding inhibitors. Biochimica et Biophysica Acta 185 269-286.

Morton NM, Holmes MC, Fievet C, Staels B, Tailleux A, Mullins JJ \& Seckl JR 2001 Improved lipid and lipoprotein profile, hepatic insulin sensitivity, and glucose tolerance in 11 $\beta$-hydroxysteroid dehydrogenase type 1 null mice. Journal of Biological Chemistry 276 41293-41300.

Morton NM, Paterson JM, Masuzaki H, Holmes MC, Staels B, Fievet C, Walker BR, Flier JS, Mullins JJ \& Seckl JR 2004 Novel adipose tissuemediated resistance to diet-induced visceral obesity in $11 \beta$-hydroxysteroid dehydrogenase type 1-deficient mice. Diabetes 53 931-938.

Olefsky JM 1975 Effect of dexamethasone on insulin binding, glucose transport, and glucose oxidation of isolated rat adipocytes. Journal of Clinical Investigation 56 1499-1508.

Ozols J 1993 Isolation and the complete amino acid sequence of lumenal endoplasmic reticulum glucose-6-phosphate dehydrogenase. PNAS 90 5302-5306.

Paterson JM, Morton NM, Fievet C, Kenyon CJ, Holmes MC, Staels B, SecklJR \& Mullins JJ 2004 Metabolic syndrome without obesity: hepatic overexpression of $11 \beta$-hydroxysteroid dehydrogenase type 1 in transgenic mice. PNAS 101 7088-7093.

Paulmyer-Lacroix O, Boullu S, Oliver C, Alessi MC \& Grino M 2002 Expression of the mRNA coding for 11 $\beta$-hydroxysteroid dehydrogenase type 1 in adipose tissue from obese patients: an in situ hybridization study. Journal of Clinical Endocrinology and Metabolism 87 2701-2705.

Qiao L, Maclean PS, Schaack J, Orlicky DJ, Darimont C, Pagliassotti M, Friedman JE \& Shao J 2005 C/EBPalpha regulates human adiponectin gene transcription through an intronic enhancer. Diabetes 54 1744-1754.

Rask E, Walker BR, Soderberg S, Livingstone DE, Eliasson M, Johnson O, Andrew R \& Olsson T 2002 Tissue-specific changes in peripheral cortisol metabolism in obese women: increased adipose $11 \beta$-hydroxysteroid dehydrogenase type 1 activity. Journal of Clinical Endocrinology and Metabolism 87 3330-3336.

Richon VM, Lyle RE \& McGehee RE, Jr 1997 Regulation and expression of retinoblastoma proteins p107 and p130 during 3T3-L1 adipocyte differentiation. Journal of Biological Chemistry 272 10117-10124.

Ricketts ML, Shoesmith KJ, Hewison M, Strain A, Eggo MC \& Stewart PM 1998 Regulation of $11 \beta$-hydroxysteroid dehydrogenase type 1 in primary cultures of rat and human hepatocytes. Journal of Endocrinology 156 159-168.

Rosen ED \& MacDougald OA 2006 Adipocyte differentiation from the inside out. Nature Reviews. Molecular Cell Biology 7 885-896. 
Shafqat N, Elleby B, Svensson S, Shafqat J, Jornvall H, Abrahmsen L \& Oppermann U 2003 Comparative enzymology of $11 \beta$-hydroxysteroid dehydrogenase type 1 from glucocorticoid resistant (guinea pig) versus sensitive (human) species. Journal of Biological Chemistry 278 2030-2035.

Slavin BG, Ong JM \& Kern PA 1994 Hormonal regulation of hormonesensitive lipase activity and $\mathrm{mRNA}$ levels in isolated rat adipocytes. Journal of Lipid Research 35 1535-1541.

Stewart PM, Boulton A, Kumar S, Clark PM \& Shackleton CH 1999 Cortisol metabolism in human obesity: impaired cortisone $\rightarrow$ cortisol conversion in subjects with central adiposity. Journal of Clinical Endocrinology and Metabolism 84 1022-1027.

Tomlinson JW, Sinha B, Bujalska I, Hewison M \& Stewart PM 2002 Expression of $11 \beta$-hydroxysteroid dehydrogenase type 1 in adipose tissue is not increased in human obesity. Journal of Clinical Endocrinology and Metabolism 87 5630-5635.

Tomlinson JW, Moore JS, Clark PM, Holder G, Shakespeare L \& Stewart PM 2004 Weight loss increases $11 \beta$-hydroxysteroid dehydrogenase type 1 expression in human adipose tissue. Journal of Clinical Endocrinology and Metabolism 89 2711-2716.

Valsamakis G, Anwar A, Tomlinson JW, Shackleton CH, McTernan PG, Chetty R, Wood PJ, Banerjee AK, Holder G, Barnett AH et al. 2004 $11 \beta$-hydroxysteroid dehydrogenase type 1 activity in lean and obese males with type 2 diabetes mellitus. Journal of Clinical Endocrinology and Metabolism 89 4755-4761.

Walker BR, Connacher AA, Lindsay RM, Webb DJ \& Edwards CR 1995 Carbenoxolone increases hepatic insulin sensitivity in man: a novel role for 11-oxosteroid reductase in enhancing glucocorticoid receptor activation. Journal of Clinical Endocrinology and Metabolism 80 3155-3159.

Walker EA, Clark AM, Hewison M, Ride JP \& Stewart PM 2001 Functional expression, characterization, and purification of the catalytic domain of human 11ß-hydroxysteroid dehydrogenase type 1. Journal of Biological Chemistry $27621343-21350$.

White PC, Mune T \& Agarwal AK 1997 11ß-Hydroxysteroid dehydrogenase and the syndrome of apparent mineralocorticoid excess. Endocrine Reviews 18 135-156.

Wolf G 1999 The molecular mechanism of the stimulation of adipocyte differentiation by a glucocorticoid. Nutrition Reviews $\mathbf{5 7} 324-326$.

Wu Z, Bucher NL \& Farmer SR 1996 Induction of peroxisome proliferatoractivated receptor gamma during the conversion of $3 \mathrm{~T} 3$ fibroblasts into adipocytes is mediated by $\mathrm{C} / \mathrm{EBP} \beta, \mathrm{C} / \mathrm{EBP} \delta$, and glucocorticoids. Molecular and Cellular Biology 16 4128-4136.

Yang S, Xu X \& Bjorntorp P 1993 Effects of dexamethasone on primarily cultured newly differentiated rat adipocytes from different adipose tissue regions. Obesity Research 1 99-105.

Received in final form 26 February 2008

Accepted 4 March 2008

Made available online as an Accepted Preprint 4 March 2008 